\title{
VEGETATION ECOLOGY OF THE SIMILIPAL BIOSPHERE RESERVE, ORISSA, INDIA
}

\author{
R.K. MISHRA ${ }^{1 *}-$ V.P. UPADHYAY ${ }^{2}-$ R.C. MOHANTY ${ }^{1}$ \\ ${ }^{\text {I}}$ Environmental Biology Research Laboratory, Department of Botany, \\ Utkal University, Bhubaneshwar - 751004 \\ ${ }^{2}$ Ministry of Environment and Forests, North East Regional Office, \\ Shillong - 793003 \\ *Corresponding author \\ e-mail:vpupadhyay@gmail.com \\ (Received $26^{\text {th }}$ November 2006 ; accepted $23^{\text {rd }}$ January 2008)
}

\begin{abstract}
Vegetation analysis of the forest ecosystem of Similipal Biosphere Reserve (SBR) was carried out at 10 sites to study changes in structure and composition in plant community distributed in the core (undisturbed) and buffer (disturbed) areas of the reserve. The study reveals a higher number of herbs and shrubs and a lower number of trees in the buffer area indicating greater anthropogenic disturbance. Total tree basal area varied from 48.7 to $78.61 \mathrm{~m}^{2} \mathrm{ha}^{-1}$ in the buffer area and 81.4 to $104.9 \mathrm{~m}^{2} \mathrm{ha}^{-1}$ in the core area. The density of saplings and seedlings was nearly equal both at the disturbed and undisturbed sites. However, the rate of conversion of saplings to trees was greater at undisturbed sites. The lower rate of conversion at disturbed sites is due to the removal of seedlings of most of the tree species. The high herb diversity $(2.14-3.50)$ and low tree diversity $(2.14-2.98)$ in buffer area is a result of Environmental openings providing greater opportunity for the recruitment of herbs and shrubs. The presence of only a few individuals of major tree species in larger diameter classes and more in young diameter classes in buffer areas indicate that the plant community was subjected to disturbance and are in the regenerating stage. Greater fluctuation in the species / genus ratio in the herbaceous species at sites of the buffer area in comparison to core area has led to variation in developmental status of plant communities among the core and buffer areas of the reserve. However, the presence of the seedlings of dominant tree species in the buffer area may help in the restoration of the plant communities in the long-run, provided protection means are strengthened and biotic stress reduced.
\end{abstract}

Keywords: Disturbance index, diversity, regeneration, community, succession, India

\section{Introduction}

Similipal Forest Ecosystem was brought into the Man and Biosphere Programme of UNESCO by declaring it as a Biosphere Reserve by the Government of India in 1994. Understanding the disturbance regimes of a forest landscape and its management under natural and semi natural conditions is essential for conservation of biological diversity (Spies and Turner, 1999). Disturbance is an extraordinary event and human generated deviation from the normal successional development of equilibrium communities (Oliver and Larson, 1990). Biodiversity is the totality of genes, species and ecosystem in a region. Apart from natural disturbances, human induced impacts have caused a significant loss to biodiversity especially in underdeveloped tropical regions. These regions have a greater diversity of plants and animals in natural habitats. Conservation biologists warn that 25 percent of all species could become extinct during the next twenty to thirty years. The loss of species is accelerating due to fragmentation of natural habitats. In the Similipal Biosphere Reserve (SBR) chronic disturbances are caused by people for their subsistence need. People remove a fraction of the forest biomass in the form of grazing, lopping, surface burning and litter removal at regular time intervals 
(Raut and Behera, 1997; Parida, 1997). Illicit cutting and removal of timber has also now become a prevalent practice, which impacts the regeneration potential of sites. The problem with these forms of forest disturbances is that the plants often do not have time to recover adequately and thus, these impacts affect the ecosystem succession of the communities.

Champion and Seth (1968) and Saxena and Brahmam (1989) have described the species composition of SBR. Some productivity-related parameters of the keystone species of SBR have been studied by Bal (2002). A comprehensive study on the structural parameters i.e. Phytosociology of tree, shrub and herb species of SBR has been carried out by Mishra et al. (2003). The present study deals with changes in vegetation diversity, composition and regeneration pattern of tree species in SBR in relation to natural and anthropogenic disturbances.

\section{Materials and methods}

The study area (SBR) is located between $21^{\circ} 28^{\prime}-22^{\circ} 08^{\prime} \mathrm{N}$ latitude and $86^{\circ} 04^{\prime}$ $86^{\circ} 37^{\prime}$ E longitude and with a range in elevation of 80 to $869 \mathrm{~m}$. For a detailed study of plant diversity and other vegetational parameters, the area was divided into 10 randomly selected sites in East, West, North and South regions of the reserve.

The climate is influenced by a monsoon pattern of rainfall. The annual rainfall is $3450 \mathrm{~mm}$; three-fourths of which occurs in the rainy season (mid June to September). The mean monthly maximum temperature ranges between $34.4^{\circ} \mathrm{C}$ (May) and $37.4{ }^{\circ} \mathrm{C}$ (June), and minimum between $7.2^{\circ} \mathrm{C}$ (December) and $11.1{ }^{\circ} \mathrm{C}$ (January).

Vegetation analysis was conducted during 2000-2001 for all the three layers of the forest i.e. trees, shrubs and herbs. The species were identified with flora guides including Saxena and Brahmam, 1994-1996 (Haines, 1921-25). The tree layer was analyzed by sampling 20 quadrats of $10 \times 10 \mathrm{~m}$ size at each site. The size and number of samples were determined using the method of Misra (1968) and Kershaw (1973). The abundance, density and frequency were calculated for the species. IVI was determined as the sum of the relative frequency, relative density and relative dominance for tree layer only. The distribution pattern of different species was studied using the ratio of abundance to frequency (Whitford, 1949) and the degree of disturbance following Pandey and Shukla (1999). The physical condition of each individual tree present inside the $10 \times 10 \mathrm{~m}$ quadrat was noted under normal and damaged categories. The trees involved under normal categories were the healthy individuals. The damaged category included the individuals that were partly broken at the top, partly dry or had recently fallen. The Individuals that were standing dead, cut stumps and completely dry were also recorded. Because such plants create problem for identification, they were not identified to species. Trees were $>31 \mathrm{~cm}$ cbh (circumference at breast height), saplings were $10-31 \mathrm{~cm}$ cbh and seedlings were $<10 \mathrm{~cm}$ cbh (Knight, 1975). The shrub and herbs layers were analyzed by randomly placing 20 quadrats of 5 x $5 \mathrm{~m}$ size and $1 \mathrm{x} 1 \mathrm{~m}$ size respectively at each site during the post monsoon season. The diversity index at each site was computed by using Shannon- Wiener information function (Shannon-Wiener, 1963) and concentration of dominance by Simpson's index (Simpson, 1949), evenness and richness index following Pielou (1975) and Margalef (1958), respectively. The species/genus ratio (S/G) was computed following Ricklefs and Miller (2000) to study the degree of succession. 


\section{Results}

\section{Inventory of vascular plants}

A total of 203 species were recorded from the study area, out of which 98 were tree species, 29 shrub and 76 herb species. Thus only approximately 19\% of the estimated flora of Similipal (Saxena and Brahmam, 1989) was covered in the study. There was a considerable difference in the species number among the study sites with site-2, being the richest having 64 species and the sites 6 and 9 having the lowest number of species (42). The other study sites showed an intermediate range (Table-1).

Table 1. Characteristics of study sites in Similipal Biodiversity Reserve in Orissa, India

\begin{tabular}{c|c|c|c|c|c|c|c}
\hline Site & Aspect & Elevation & $\begin{array}{c}\text { Normal } \\
\text { trees }\end{array}$ & $\begin{array}{c}\text { Damaged } \\
\text { trees }\end{array}$ & $\begin{array}{c}\text { Total } \\
\text { (Normal + } \\
\text { Damaged) }\end{array}$ & $\begin{array}{c}\text { D.I. } \\
(\boldsymbol{\%})\end{array}$ & $\begin{array}{c}\text { Level of } \\
\text { interference }\end{array}$ \\
\hline Podadiha $\left(\mathrm{S}_{1}\right)$ & $\begin{array}{c}\text { South- } \\
\text { East }\end{array}$ & 80 & 109 & 84 & 193 & 43.52 & $\mathrm{HB}$ \\
Bangirposi $\left(\mathrm{S}_{2}\right)$ & East & 226 & 107 & 81 & 188 & 43.68 & $\mathrm{HB}$ \\
Handipuhan $\left(\mathrm{S}_{3}\right)$ & North & 280 & 111 & 96 & 207 & 46.38 & $\mathrm{HB}$ \\
Ghodabindha( $\left.\mathrm{S}_{4}\right)$ & West & 557 & 105 & 82 & 187 & 43.85 & $\mathrm{HB}$ \\
Kendumundi $\left(\mathrm{S}_{5}\right)$ & West & 400 & 157 & 57 & 214 & 26.63 & $\mathrm{MB}$ \\
Kalika & West & 468 & 138 & 44 & 182 & 24.17 & $\mathrm{MB}$ \\
Prasad $\left(\mathrm{S}_{6}\right)$ & & & & 25 & 195 & 12.80 & $\mathrm{NB}$ \\
Joranda $\left(\mathrm{S}_{7}\right)$ & North & 681 & 170 & 29 & 197 & 14.72 & $\mathrm{NB}$ \\
Chahala $\left(\mathrm{S}_{8}\right)$ & North & 774 & 168 & 29 & 16.22 & $\mathrm{NB}$ \\
UBK $\left(\mathrm{S}_{9}\right)^{*}$ & South & 824 & 186 & 36 & 222 & 15.05 & $\mathrm{NB}$ \\
Jenabil $\left(\mathrm{S}_{10}\right)$ & South & 869 & 175 & 31 & 206 &
\end{tabular}

D.I. (Disturbance Index) $=$ Percentage of damaged individuals of the total number of woody individuals per $2000 \mathrm{~m}^{2}$ area.*- UBK - Upper Barakanda.

HB- High biotic interference; MB- Moderate biotic interference; NB- No biotic interference.

Middle elevation sites had a lower number of species than lower and higher elevation sites. Disturbed sites contained more species than undisturbed and moderately disturbed sites. Disturbances occurred either in the form of recurring soil erosion (natural) or anthropogenic disturbances such as grazing, lopping, surface burning and illegal cutting of trees (Table 1 and 2).

Table 2. Spatial distribution of species

\begin{tabular}{c|c|c|c|c}
\hline Site & Tree & Shrub & Herb & Total \\
\hline S -1 & 29 & 8 & 16 & 53 \\
S - & 31 & 12 & 21 & 64 \\
S -3 & 20 & 10 & 13 & 43 \\
S - & 27 & 10 & 13 & 50 \\
S - 5 & 36 & 7 & 8 & 51 \\
S - 6 & 23 & 7 & 12 & 42 \\
S - & 31 & 8 & 10 & 49 \\
S - 8 & 36 & 8 & 10 & 54 \\
S - 9 & 19 & 9 & 14 & 42 \\
S-10 & 31 & 9 & 12 & 52 \\
\hline
\end{tabular}




\section{Structure of the vegetation}

Importance value index (IVI) of tree species indicated that Shorea robusta Gaertn.f., was the dominant species at all the study sites in the tree and sapling layers of the reserve followed by Dillenia pentagyna, Terminalia alata, Anogeissus latifolia, Schleichera oleosa, Syzygium cumini. The IVI of the dominant tree species was less (111.51 to 151.37$)$ at the disturbed sites and more (180.64 to 235.63) at the undisturbed sites. While intermediate range of IVI (158.58-207.73) of dominant tree species was found in the moderately disturbed study sites. No such clear-cut difference was observed in the IVI of dominant tree species due to altitude or aspect (Table 3).

The tree density across the sites ranged from 650 to 970 individuals ha $^{-1}$ and the basal area from 48.71 to $104.92 \mathrm{~m}^{2} \mathrm{ha}^{-1}$. The density and basal area of undisturbed sites was higher than the disturbed sites. However, the difference in density and basal area of the shrub and sapling layer among the disturbed and undisturbed sites of the reserve was not distinct. Diversity of herb species was much higher at the undisturbed sites. (Table 4).

\section{Distribution pattern}

The distribution pattern of trees, shrubs, herbs, saplings and seedlings for all study sites is shown in Table 5. Odum (1971) stated that under natural conditions, a clumped distribution of plants is normal. A higher percentage of random and regular distribution reflects the greater magnitude of disturbance' such as grazing and lopping in natural forest stands. All the vegetational layers showed generally clumped type of distribution in the present study.

Table 3. Importance Value Index (IVI) of most dominant tree species of Similipal Biosphere Reserve

\begin{tabular}{|c|c|c|c|c|c|c|c|c|c|c|}
\hline $\begin{array}{c}\text { Name of the plant } \\
\text { species }\end{array}$ & S-1 & S-2 & S-3 & S-4 & S-5 & S-6 & S-7 & S-8 & S-9 & S-10 \\
\hline $\begin{array}{c}\text { Adina cordifolia } \\
\text { (Roxb.) Hook. F. ex. } \\
\text { Brandis }\end{array}$ & 7.85 & 5.38 & 18.03 & 2.17 & 10.14 & 8.32 & 7.05 & 3.70 & - & 3.73 \\
\hline $\begin{array}{c}\text { Anogeissus latifolia } \\
\text { Roxb. Ex DC) Wall } \\
\text { ex. Bedd. }\end{array}$ & 14.22 & 14.4 & 13.60 & 25.22 & 34.06 & 11.64 & 25.0 & 9.65 & - & - \\
\hline Bombax ceiba L. & - & 1.93 & - & - & 3.32 & - & 4.03 & 6.35 & 5.14 & 27.43 \\
\hline $\begin{array}{c}\text { Dillenia pentagyna } \\
\text { Roxb. }\end{array}$ & 14.15 & 8.80 & 5.58 & - & 6.9 & 8.11 & 15.73 & 57.43 & 20.58 & 54.13 \\
\hline $\begin{array}{c}\text { Shorea robusta Gaertn. } \\
\text { f. }\end{array}$ & 37.12 & 41.77 & 52.69 & 84.76 & 73.43 & $\begin{array}{c}149.9 \\
-107.4\end{array}$ & 51.27 & $\begin{array}{c}130.1 \\
5\end{array}$ & 53.75 \\
\hline $\begin{array}{c}\text { Syzygium cumini (L.) } \\
\text { Skeels }\end{array}$ & - & 7.16 & 8.99 & - & 2.69 & 14.71 & 1.97 & 23.95 & 12.12 & 14.59 \\
\hline $\begin{array}{c}\text { Syzygium cerasoides } \\
\text { Roxb.) Raizada }\end{array}$ & 6.53 & - & - & - & 4.04 & 9.34 & 11.76 & 4.02 & 14.05 & 7.71 \\
\hline $\begin{array}{c}\text { Schleichera oleosa } \\
\text { (Lour.) Oken }\end{array}$ & 15.1 & 8.29 & 5.25 & 11.15 & 6.49 & - & 5.19 & 13.19 & 3.57 & 13.59 \\
\hline $\begin{array}{c}\text { Terminalia alata } \\
\text { Heyne ex Roth. }\end{array}$ & 29.23 & 22.13 & 13.38 & 21.49 & 13.27 & 3.16 & 25.09 & 11.08 & 46.57 & 15.52 \\
\hline $\begin{array}{c}\text { Terminalia chebula } \\
\text { Retz. }\end{array}$ & 3.03 & 1.65 & 2.69 & 5.58 & 4.24 & 2.53 & 2.57 & - & 3.45 & 5.16 \\
\hline
\end{tabular}


Table 4. Importance Value Index (IVI) of most dominant tree species of Similipal Biosphere Reserve Density (individuals $h a-1$ ) and Basal area (m 2 ha-1) of different vegetational layers of Similipal Biosphere Reserve.

\begin{tabular}{|c|c|c|c|c|c|c|c|}
\hline \multirow{2}{*}{ Site } & \multicolumn{5}{|c|}{ Density } & \multicolumn{3}{c|}{ Basal area } \\
\cline { 2 - 8 } & Tree & Saplings & Shrubs & Seedlings & Herbs & Tree & Saplings \\
\hline S - 1 & 680 & 1500 & 640 & 12.40 & 42.4 & 52.36 & 7.07 \\
\hline S - 2 & 675 & 1160 & 600 & 9.00 & 37.5 & 59.54 & 6.84 \\
\hline S -3 & 715 & 1220 & 580 & 18.05 & 33.0 & 48.71 & 6.57 \\
\hline S - 4 & 650 & 920 & 580 & 8.00 & 21.0 & 49.13 & 6.61 \\
\hline S - 5 & 845 & 1320 & 400 & 9.00 & 6.0 & 68.99 & 6.11 \\
\hline S - 6 & 750 & 2040 & 460 & 16.00 & 5.0 & 78.61 & 5.68 \\
\hline S - 7 & 810 & 1200 & 280 & 20.00 & 3.0 & 81.35 & 4.40 \\
\hline S - - & 875 & 1380 & 200 & 9.00 & 2.0 & 88.59 & 5.18 \\
\hline S - 9 & 970 & 1620 & 180 & 8.70 & 2.5 & 84.86 & 7.21 \\
\hline S -10 & 895 & 1720 & 260 & 17.60 & 2.0 & 104.92 & 6.67 \\
\hline
\end{tabular}

The tree layer exhibited less clumped distribution at the disturbed sites than the undisturbed and moderately disturbed study sites. The distribution pattern of other vegetational layers did not show any distinct difference among the study sites. The trees at Podadiha, Bangirposi, Handipuhan and Ghodabindha are faced with more biotic disturbance; Kendumundi and Kalika Prasad with moderate biotic disturbance; and Joranda, Chahala, UBK and Jenabil with no biotic disturbance.

Table 5. Distribution pattern (\%) of plant layers.

\begin{tabular}{|c|c|c|c|c|}
\hline Site & Stratum & Regular & Random & Contiguous \\
\hline \multirow{4}{*}{ HB } & Tree & $17-23$ & $33-45$ & $35-48$ \\
& Sapling & $4-10$ & $24-46$ & $50-67$ \\
& Shrub & $2-5$ & $28-40$ & $57-72$ \\
& Herb & $0-5$ & $5-20$ & $75-95$ \\
& Seedling & $0-4$ & $3-14$ & $82-87$ \\
\hline \multirow{4}{*}{ MB } & Tree & $9-14$ & $33-35$ & $53-57$ \\
& Sapling & $5-8$ & $12-25$ & $69-81$ \\
& Shrub & $5-6$ & $22-42$ & $53-72$ \\
& Herb & $0-5$ & $8-20$ & $75-92$ \\
& Seedling & $0-0$ & $3-7$ & $93-97$ \\
\hline \multirow{4}{*}{ NB } & Tree & $0-5$ & $19.44-32.25$ & $67.74-77.78$ \\
& Sapling & $0-5$ & $7.69-25$ & $70-88.46$ \\
& Shrub & $0-8$ & $30-40$ & $55-61$ \\
& Herb & $0-0$ & $3-24$ & $76-97$ \\
& Seedling & $0-0$ & $6.89-15.38$ & $84.61-93.10$ \\
\hline
\end{tabular}

Species diversity, concentration of dominance and some mathematical indices of different vegetational layers of the study sites are given in Table 6. Measurement of biodiversity of specific area (local scale) on the basis of species richness does not provide a complete understanding about the individuals of the species in an ecosystem as it suffers from the lack of evenness or equitability. 
Table 6. Species diversity (SD), Concentration of dominance (CD) species richness (SR) and species evenness (SE) of different forest strata

\begin{tabular}{|c|c|c|c|c|c|c|}
\hline \multirow{2}{*}{ Site } & \multirow{2}{*}{ Parameters } & \multicolumn{5}{|c|}{ Vegetational Layer } \\
\hline & & Tree & Sapling & Shrub & Seedling & Herb \\
\hline \multirow{4}{*}{$S-1$} & SD & 2.139 & 2.512 & 2.676 & 2.151 & 2.519 \\
\hline & $\mathrm{CD}$ & 0.103 & 0.113 & 0.095 & 0.178 & 0.117 \\
\hline & SR & 5.69 & 3.68 & 4.135 & 3.156 & 2.793 \\
\hline & SE & 0.635 & 0.873 & 0.887 & 0.759 & 0.895 \\
\hline \multirow{4}{*}{$S-2$} & SD & 2.98 & 2.135 & 2.114 & 1.746 & 3.496 \\
\hline & $\mathrm{CD}$ & 0.072 & 0.166 & 0.176 & 0.318 & 0.092 \\
\hline & SR & 6.116 & 2.875 & 3.301 & 2.962 & 2.537 \\
\hline & SE & 0.868 & 0.832 & 0.851 & 0.629 & 1.209 \\
\hline \multirow{4}{*}{$S-3$} & SD & 2.426 & 2.033 & 2.067 & 2.905 & 2.446 \\
\hline & $\mathrm{CD}$ & 0.131 & 0.192 & 0.161 & 0.140 & 0.128 \\
\hline & SR & 3.828 & 2.676 & 2.532 & 2.732 & 1.815 \\
\hline & SE & 0.809 & 0.818 & 0.817 & 1.072 & 0.798 \\
\hline \multirow{4}{*}{$S-4$} & SD & 2.072 & 2.424 & 2.137 & 2.446 & 2.334 \\
\hline & $\mathrm{CD}$ & 0.115 & 0.111 & 0.134 & 0.205 & 0.140 \\
\hline & SR & 4.142 & 3.202 & 2.871 & 3.498 & 1.918 \\
\hline & SE & 0.629 & 0.918 & 0.928 & 0.846 & 1.014 \\
\hline \multirow{4}{*}{$S-5$} & SD & 2.887 & 2.465 & 1.785 & 2.615 & 2.138 \\
\hline & $\mathrm{CD}$ & 0.093 & 0.113 & 0.191 & 0.128 & 0.136 \\
\hline & SR & 6.823 & 4.043 & 2.004 & 2.962 & 1.677 \\
\hline & SE & 0.806 & 0.853 & 0.917 & 0.822 & 0.980 \\
\hline \multirow{4}{*}{ S - 6} & SD & 1.994 & 1.821 & 1.996 & 1.71 & 2.152 \\
\hline & $\mathrm{CD}$ & 0.313 & 0.106 & 0.116 & 0.430 & 0.139 \\
\hline & SR & 4.390 & 2.581 & 2.895 & 1.567 & 2.281 \\
\hline & SE & 0.636 & 0.794 & 0.881 & 0.822 & 0.866 \\
\hline \multirow{4}{*}{ S - 7} & SD & 2.896 & 1.956 & 1.955 & 2.105 & 2.043 \\
\hline & $\mathrm{CD}$ & 0.193 & 0.216 & 0.158 & 0.257 & 0.188 \\
\hline & SR & 5.897 & 2.676 & 2.377 & 3.673 & 1.901 \\
\hline & SE & 0.843 & 0.787 & 0.940 & 0.743 & 0.797 \\
\hline \multirow{4}{*}{$S-8$} & SD & 3.083 & 2.543 & 2.023 & 2.521 & 1.803 \\
\hline & $\mathrm{CD}$ & 0.07 & 0.083 & 0.139 & 0.142 & 0.190 \\
\hline & SR & 6.776 & 3.833 & 2.818 & 4.370 & 1.465 \\
\hline & SE & 0.86 & 0.864 & 0.973 & 0.828 & 0.946 \\
\hline \multirow{4}{*}{ S - 9} & SD & 1.798 & 2.379 & 2.082 & 3.251 & 2.048 \\
\hline & $\mathrm{CD}$ & 0.316 & 0.136 & 0.148 & 0.139 & 0.179 \\
\hline & SR & 3.417 & 3.729 & 2.525 & 4.116 & 1.837 \\
\hline & SE & 0.611 & 0.839 & 0.982 & 1.308 & 0.723 \\
\hline \multirow{4}{*}{ S-10 } & SD & 3.107 & 2.763 & 2.043 & 1.913 & 2.084 \\
\hline & $\mathrm{CD}$ & 0.069 & 0.093 & 0.136 & 0.207 & 0.199 \\
\hline & SR & 5.803 & 3.723 & 2.509 & 2.245 & 2.071 \\
\hline & $\mathrm{SE}$ & 0.905 & 0.786 & 0.841 & 0.798 & 0.839 \\
\hline
\end{tabular}

It was observed that the richness index ranged from 3.48 to 6.12 (tree layer), 1.47 to 2.79 (herb layer), 2.00 to 4.14 (shrub layer), 2.58 to 4.04 (sapling layer) and 1.57 to 4.37 (seedling layer) and equitability showed little variation across the sites which ranged from 0.61 to 0.91 (tree layer), 0.72 to 1.21 (herb layer), 0.82 to 0.98 (shrub layer), 0.79 to 0.92 (sapling layer) and 0.74 to 1.31 (seedling layer). Shannon Wiener's index of diversity is one of the popular measures of species diversity. It ranged from 1.80 to $3.11,1.80$ to 3.50 and 1.79 to 2.68 for tree, herb and shrub layers, respectively, across all sites. The species diversity of the tree layer generally was highest at the undisturbed 
sites (except UBK) and lowest at the disturbed sites (except Bangirposi), but herb and shrub layers exhibited an opposite trend.

We considered seven cbh classes including seedlings $(<10 \mathrm{~cm})$, saplings $(10-31 \mathrm{~cm})$, bole $(32-66 \mathrm{~cm})$, post bole $(67-101 \mathrm{~cm})$, small $(102-136 \mathrm{~cm})$, large $(137-171 \mathrm{~cm})$ and over mature $(>171 \mathrm{~cm})$ following Singh et al. (1986). Density of woody tree species in different cbh classes in undisturbed and moderately disturbed study sites showed a continuous pattern in the order of seedling $>$ sapling $>$ bole $>$ Post bole $>$ small $>$ large $>$ over mature tress. However, on disturbed study sites, the order was seedling $>$ sapling $>$ bole $<$ post bole < small >large $>$ over mature in case of Shorea robusta and seedling $>$ sapling $>$ bole $<$ post bole $>$ small $>$ large $=$ over mature incase of Dillenia pentagyna and Terminalia alata.

\section{Stand Structure and Size Class Distribution:}

Cbh distribution of tree species among sites is largely controlled by the density of overstorey species and the pattern of regeneration can be described by the size distribution as reported by Singh et al. (1986). Density of individuals of the most dominant tree species such as Shorea robusta, Dillenia pentagyna and Terminalia alata in different cbh classes of disturbed, undisturbed and moderately disturbed study sites is presented in Table 7.

Table 7. Distribution (Number of individuals ha -1 ) of most dominant tree species in the disturbed, moderately disturbed and undisturbed study sites of Similipal Biosphere Reserve

\begin{tabular}{|c|c|c|c|c|c|c|c|c|c|}
\hline \multicolumn{10}{|c|}{ Dominant tree species } \\
\hline \multirow{2}{*}{$\begin{array}{l}\text { Girth class } \\
\quad(\mathrm{cm})\end{array}$} & \multicolumn{3}{|c|}{ Shorea robusta } & \multicolumn{3}{|c|}{ Terminalia alata } & \multicolumn{3}{|c|}{ Dillenia pentagyna } \\
\hline & DS & MDS & UDS & DS & MDS & UDS & DS & MDS & UDS \\
\hline $\begin{array}{c}<10 \\
\text { (seedlings) }\end{array}$ & 16670 & 15600 & 15250 & 2334 & 2500 & 2400 & 1980 & 2050 & 2250 \\
\hline $\begin{array}{c}10-31 \\
\text { (Saplings) }\end{array}$ & 387 & 370 & 385 & 135 & 160 & 140 & 58 & 72 & 75 \\
\hline $\begin{array}{l}32-66 \\
\text { (Bole) }\end{array}$ & 24 & 90 & 117 & 20 & 30 & 70 & 15 & 14 & 15 \\
\hline $\begin{array}{c}67-101 \\
\text { (Post Bole) }\end{array}$ & 58 & 64 & 92 & 45 & 25 & 60 & 28 & 11 & 13 \\
\hline $\begin{array}{l}102-136 \\
\text { (Small) }\end{array}$ & 84 & 34 & 39 & 20 & 10 & 35 & 10 & 08 & 11 \\
\hline $\begin{array}{c}137-171 \\
\text { (Large) }\end{array}$ & 28 & 30 & 34 & 05 & 05 & 25 & 0 & 06 & 08 \\
\hline $\begin{array}{c}>171 \\
\text { (Over mature) }\end{array}$ & 10 & 18 & 24 & 05 & 05 & 10 & 0 & 05 & 06 \\
\hline
\end{tabular}

DS: Disturbed sites, MDS Moderately disturbed sites, UDS: Undisturbed sites 


\section{Discussion}

The forest ecosystems of Similipal Biosphere Reserve are experiencing disturbances of various magnitudes. Practices for removal of forest biomass in the form of grazing, lopping, surface burning and litter removal at a given time is a continuous disturbance affecting the stability of the ecosystem and retarding the successional processes in the area. These areas can be clearly demarcated on the basis of different phytosociological parameters of the vegetation.

Tree density in the different tropical forest has been recorded in the range of 5501800 individuals ha $^{-1}$ (Visalakshi, 1995) and 3700 individuals ha $^{-1}$ in lowland neotropical dry forests (Gentry, 1995). In the present study the tree density ranged from 650 to 970 individuals ha ${ }^{-1}$, which is comparable to tropical forests. Tree and sapling density were higher in the core area (undisturbed sites) compared to buffer area (disturbed sites). Higher anthropogenic disturbances in the buffer area has also led to the elimination of seedlings of most of the species (table-4).

The total basal area across the sites ranged from 48.7 to $104.9 \mathrm{~m}^{2}$ ha ${ }^{-1}$ (Table - 4). The differences in basal area of tree layer among study sites may be due to difference in altitude, species composition, age of trees, degree of disturbance and successional stages of the stands. The value obtained for basal area in the present study is comparable to the Indian tropical forests (Visalakshi, 1995).

Importance value index of Shorea robusta in the present study area located at 80$869 \mathrm{~m}$ altitude ranged from 37.12 to 149.92 which is comparable with the IVI of 127 (300-900m) and 181 (up to $1200 \mathrm{~m}$ ) reported for Shorea robusta in mixed forests of Central Himalaya (Tewari \& Singh, 1987). The change in IVI of Shorea robusta among the study sites is due to the change in species composition, disturbance and altitude (Procter et al., 1988). Suderpandian and Swamy (2000) reported that the Dipterocarpaceous members could not be found at higher altitudes $(1150 \mathrm{~m})$.

The species richness of trees ranged from 19 to 36 . Other studies elsewhere have reported a similar range of species richness (Brockway, 1998; Tripathi, 2001). In the present study the species richness is positively correlated with species diversity $(r=0.82$ and 0.82 at $\mathrm{p}<0.01$ for trees and saplings, $\mathrm{r}=0.92$ for shrubs at $\mathrm{p}<0.001$ and $\mathrm{r}=0.66$ for herbs at $\mathrm{p}<0.05$ ). While species diversity (Shannon wiener diversity index) and dominance (Simpson's index) are inversely related to each other $(r=-0.70,-0.65$ and 0.72 at $\mathrm{p}<0.05$ for trees, saplings and shrubs, respectively and, $r=-0.82$ and 0.81 at $\mathrm{p}<$ 0.01 for seedlings and herbs, respectively). The tree density and shrub diversity had a weak negative relation with each other and the relationship is not being significant. Tree density and herb diversity $(r=-0.65 \mathrm{p}<0.05)$ were highly negatively correlated, establishing that the open canopy provides opportunity for the recruitment of shrubs and herbs.

The diversity index is generally higher for tropical forests and the reported range is 5.1 and 5.4 for young and old stands, respectively (Knight, 1975). Many researchers have reported the diversity value for Indian forests in the range of 0.8 to 4.1 (Parthasarthy et al., 1992; Visalakshi, 1995). Thus, the diversity values of tree species obtained in the present study is well within the reported range of Indian tropical forests. However, these values are lower than the other tropical forests (e.g. Knight, 1975) which may perhaps be due to climatic differences and high degree of natural disturbances, which are critical factors in governing the tropical forest species diversity (Foster, 1990). The lower diversity values in Indian forests may also be due to 
anthropogenic disturbances such as burning, grazing and wood collection (Jayasingam and Vivekanantharaja, 1994).

The population structure and size class distribution have generally been used by many researchers for understanding regeneration and magnitude of disturbances and future stability of tree species population in forest communities (Upreti, 1982). From the present study, the overall pattern of distribution of the trees in different chb classes reveals dominance of mature trees at the undisturbed sites and seedlings and saplings at the disturbed sites. More number of individuals of dominant tree species, such as Shorea robusta, Dillenia pentagyna and Terminalia alata in higher cbh classes were observed in the core area. This may indicate that buffer area has had more anthropogenic disturbance. A similar pattern has also been reported by Khan et al. (1987) among the disturbed and protected subtropical forest sites of northeast India.

The data on species/genus ratio helps to compare the rate of species development because high ratio indicate recent diversification (Fig.1). Tropical areas have low species/genus ratio, indicating that the tropical species have emerged over a long period of time (Ricklefs and Miller, 2000). In the present study, all the study sites show lower $\mathrm{S} / \mathrm{G}$ ratio in the tree and shrub layer and higher $\mathrm{S} / \mathrm{G}$ ratio in the herb layer, thus supporting the findings of Ricklefs and Miller (2000). Further studies on functional parameters of the ecosystem shall provide more information to establish linkages and interactions between edaphic factors, productivity, nutrient input and decomposition and structural characteristics of the vegetation of Similipal Biosphere Reserve which will help management authorities to take measures for restoration.

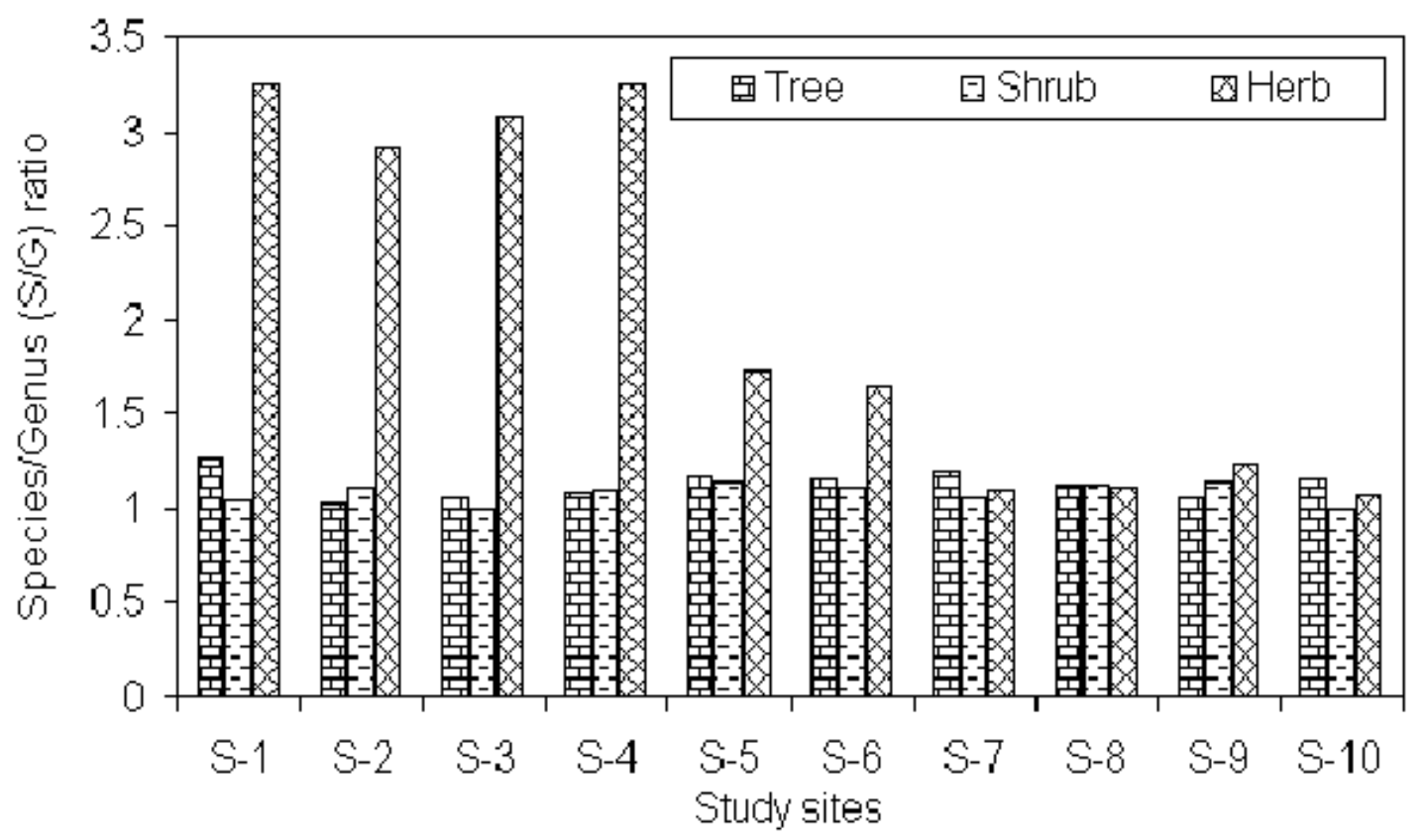

Figure 1. Species/Genus ratio of different vegetational layers of Similpal Biosphere Reserve 


\section{REFERENCES}

[1] Bal, S.(2002): Some Productivity Aspects of Ten Keystone Species of Similipal Biosphere Reserve. - Ph.D. Thesis, Utkal University, Bhubaneswar.

[2] Brockway, D.G. (1998): Forest plant diversity at local \& landscape scales in the cascade mountains of south- western Washington. - Forest Ecology and Management 109:323341.

[3] Champion, H.G. \& S.K. Seth. (1968): A Revised Survey of The Forest Types of India. Manager of Publication, Govt. of India Press, New Delhi.

[4] Foster, R.B. (1990): Heterogeneity \& disturbance in tropical vegetation. - In: Soule, M.E. and Wilcox, B.A. (eds.) Conservation Biology: An Evolutionary- Ecological Perspective. Sinauer Associates, Sunderland, pp. 75-92.

[5] Gentry, A.H. (1995): Diversity \& floristic composition of neotropical dry forests. - In: Bullock, S.H. Mooney, H.A. and Medina, E. (eds.) Seasonally Dry Tropical Forests. Cambridge University Press, Cambridge, pp. 146-194.

[6] Haines, H.H. (1925): The Botany of Bihar \& Orissa. Vol. I-III. - London, Botanical Survey of India, Calcutta (Repn.Edn. 1961)

[7] Jayasingam, T \& S. Vivekanatharaja (1994): Vegetation survey of the Wasgamuwa National Park, Srilanka. - Vegetation 13 (1): 1-8.

[8] Kershaw, K.R. (1973): Quantitative \& Dynamic Plant Ecology. - Edward Arnold Ltd., London.

[9] Khan, M.L., J.P.N. Rai, \& R.S. Tripathi. (1987): Population structure of some tree species in disturbed \& protected subtropical forests of north-east India. - Acta Oecologia 8 (3): 247-255.

[10] Knight, D.H. (1975): A phytosociological analysis of species rich tropical forest on Barro Colorado Island, Panama. - Ecological Monographs 45: 259-289.

[11] Margaleff, D.R. (1958): Information theory in ecology. - Year book of the Society for General Systems Research 3: 36-71.

[12] Mishra, R.K., V.P. Upadhyay \& R.C. Mohanty. (2003) Vegetation diversity of Similipal biosphere reserve. - E-Planet 1(1): 4-9.

[13] Misra, R. (1968): Ecology Work Book. - Oxford \& IBH Publishing Co., New Delhi.

[14] Odum, E.P. (1971) Fundamentals of Ecology. - W.B. Saunders Co., Philadelphia.

[15] Oliver, C.D. \& B.C. Larson. (1990): Forest Stand Dynamics. - Mc Graw Hill, Inc., New York.

[16] Parida, R.C. (1997): Sustainable exploitation of natural resources of Similipal. - In: Tripathy, P.C. \& Patro, S.N. (eds.) Similipal: A Natural Habitat of Unique Biodiversity. Orissa Environmental Society, Bhubaneswar, p. 139-145.

[17] Pandey, S.K. \& R.P. Shukla (1999): Plant diversity \& community patterns along the disturbance gradient in plantation forests of Sal (Shorea robusta Gaertn). - Current Science 77: 814-818.

[18] Parthasarathy, N., V. Kinhal \& L. Praveen Kumar (1992): Plant species diversity \& human impact in the tropical wet evergreen forests of Southern western Ghats. In: IndoFrench Workshop on Tropical Forest Ecosystem: Natural Functioning \& Anthropogenic Impact. French Institute, Pondichery, November, 1992.

[19] Pielou, E.C. (1975): Ecological Diversity. - John Wiley \& Sons, New York.

[20] Proctor, J., Y.F. Lee, A.M. Langley, W.R. Munro \& T. Nelson. (1988): Ecological studies of Gunung Silam, a small ultrabasic mountain in Sabh, Malaysia. I.

[21] Raut, D.K. \& G. Behera. (1997): Application of remote sensing for management of natural resources in Similipal biosphere reserve. - In : Tripathy, P.C. \& Patro, S.N. (eds.) Similipal: A Natural Habitat of Unique Biodiversity. Orissa Environmental Society, Bhubaneswar, pp. 129-138. 
[22] Ricklefs, R.E. \& G.L. Miller. (2000): Ecology. - W.H. Freeman \& Company, New York.

[23] Saxena, H.O. \& Brahmam, M. (1989): The Flora of Similipahar (Similipal), Orissa. Regional Research Laboratory, Bhubaneswar.

[24] Saxena, H.O. \& M. Brahmam. (1996): The Flora of Orissa. - Vol. I-IV Regional Research Laboratory (CSIR), Bhubaneswar \& Orissa Forest Development Corporation Ltd., Bhubaneswar.

[25] Shannon, C.E. \& W. Wiener. (1963): The Mathematical Theory of Communication. University Press, Illinois, USA.

[26] Simpson, E.H. (1949): Measurement of diversity. - Nature 163: 688.

[27] Singh, S.P., J.C. Tewari, S. Yadav \& P.K. Ralhan. (1986): Population structure of tree species in forests as an indicator of regeneration \& future stability. - Proceeding Indian Academy of Science 96(6): 443-455.

[28] Spies, T.A. \& M.G. Turner. (1999): Dynamics of forest mosaics. - In: Hunter, M.L. Jr. (ed.) Maintaining Biodiversity in Forest Ecosystems. Cambridge University press, Cambridge, U.K., pp. 95-160.

[29] Sunderpandian, S.M. \& P.S. Swamy. (2000): Forest ecosystem structure \& composition along an altitudinal gradient in the Western Ghats, South India. - Journal of Tropical Forest Science 12(1): 104-123.

[30] Tewari, A.K. \& J.S. Singh. (1987): Analysis of forest land- use \& vegetation in a part of Central Himalaya, using aerial photographs. - Environmental Conservation 14: 233-244.

[31] Tripathi, K.P. (2001): Ecology of a Rehabilitated Forest on Sodic Wasteland. - Ph.D. Thesis.

[32] Upreti, N. (1982): A Study on Phytosociology \& State of Regeneration of Oak-Forest at Nainital. - Ph.D. Thesis, Kumaum University, Nainital.

[33] Visalakshi, N. (1995): Vegetation analysis of two tropical dry evergreen forests in southern India. - Tropical Ecology 36: 117-127.

[34] Whitford, P.B. (1949): Distribution of woody plants in relation to succession \& clonal growth. - Ecology 30: 199-208. 